\title{
HUBUNGAN PENGETAHUAN TENTANG ZAT ADITIF DENGAN SIKAP PEMILIHAN MAKANAN JAJANAN SISWA SMPN 74 JAKARTA
}

\author{
Correlation Between Knowledge about Additives and Attitude about Selection of \\ Snack Food Students at SMPN 74 Jakarta
}

Sri Rahayu, Refirman D.J., Dewi Ratna Sari

Biologi / Pendidikan Biologi Fakultas MIPA Universitas Negeri Jakarta Email: dewiratnooy@yahoo.com

\begin{abstract}
The junior high school students almost every day activities of the school to get an extra snack energy after a long day at school. However, snack food in schools and surrounding areas can not be secured, including the safety of additives. To avoid students from the negative impact of food additives, the needed knowledge about the additives. Knowledge of these additives have an important role in shaping the attitude of the selection of snack food. This study aim to determine correlation between knowledge of additives and attitude about selection of snack food students at SMPN 74 Jakarta. The research was conducted at SMPN 74 Jakarta on April-May 2016. The method of this study was descriptive method with survey techniques through correlational studies. The sample of this study was 166 students. Prerequisite test results showed that the data was normally distributed and homogeneous. Regression model $\hat{Y}=127.35+2.23 \mathrm{X}$ that was significant and had a linear correlation. Based on hypothesis testing, the value of the correlation coefficient of 0.76 and a coefficient of determination of $58 \%$. Based on these results, it can be concluded that there was a positive correlation between knowledge about additives and attitude about selection of snack food students at SMPN 74 Jakarta and knowledge about additives contributed 58\% to attitude about selection of snack food students at SMPN 74 Jakarta.
\end{abstract}

\section{Keywords : Additives, attitude, knowledge, selection of snack food}

\section{PENDAHULUAN}

Pada umumnya, anak-anak usia sekolah menghabiskan sepertiga sampai setengah dari waktunya untuk beraktivitas di luar rumah antara lain di sekolah, tempat les atau bermain di sekitar rumah. Aktivitas yang tinggi ini menyebabkan mereka cepat merasa lapar sehingga mendorong mereka untuk membeli makanan jajanan yang ada di sekitarnya.

Makanan jajanan adalah makanan dan minuman yang diolah oleh produsen makanan di tempat penjualan dan disajikan sebagai makanan siap santap untuk dijual bagi masyarakat umum (Menteri Keseharan RI, 2003). Secara umum, makanan jajanan yang disukai adalah makanan yang memenuhi selera atau cita rasa yaitu dalam hal rupa, warna, bau, rasa, suhu, dan tekstur (Almatsier, 2013). Jenis makanan jajanan yang menjadi favorit bagi sebagian besar anak-anak yaitu cokelat, permen, jeli, biskuit, snack, es teh, dan es sirup (Nuraini, 2007). Agar 
makanan tampak lebih menarik, memiliki cita rasa yang baik dan tahan lama biasanya diberi zat aditif.

Purnomowati, Hidayati, dan Saparinto (2008) menyatakan bahwa zat aditif adalah bahan yang ditambahkan ke dalam makanan untuk mempengaruhi sifat dan bentuk pangan atau produk makanan. Zat aditif yang sering digunakan khususnya pada makanan jajanan yaitu pengawet, pewarna, pemanis, penyedap rasa dan aroma.

Hasil pengawasan Badan POM terhadap makanan jajanan anak sekolah pada tahun 2014 diperoleh $2.484(23,82 \%)$ dari 10.429 sampel yang tidak memenuhi syarat. Penyebab sampel tidak memenuhi syarat antara lain karena menggunakan zat aditif yang melebihi batas maksimal dan menggunakan zat aditif berbahaya yang dilarang untuk makanan seperti formalin, boraks, rhodamin B, dan metanil yellow (BPOM RI, 2014).

Zat aditif pada makanan dapat menimbulkan dampak negatif apabila dikonsumsi dengan dosis yang berlebihan misalnya keracunan, kerusakan ginjal, kelainan reproduksi dan kanker (Cahyadi, 2006). Untuk terhindar dari dampak tersebut, diperlukan adanya pengetahuan tentang zat aditif. Pengetahuan adalah hasil dari tahu yang terjadi melalui proses sensoris terhadap objek tertentu (Sunaryo, 2004).

Menurut Notoatmodjo (2007), pengetahuan memegang peranan penting dalam pembentukan suatu sikap. Sikap adalah respon seseorang terhadap stimulus atau objek tertentu, yang sudah melibatkan faktor pendapat dan emosi yang bersangkutan (senang-tidak senang, setuju-tidak setuju, baik-tidak baik, dan sebagainya) (Notoatmodjo, 2007a). Menurut hasil penelitian Sudarmawan dan Nurhayati (2013) terdapat korelasi yang positif mengenai hubungan antara pengetahuan dengan sikap. Korelasi yang positif dalam hal ini menunjukkan bahwa bahwa semakin baik pengetahuan tentang makanan jajanan maka sikap pemilihan makanan jajanan juga akan semakin baik.

Penelitian ini dilakukan di SMPN 74 Jakarta. Sekolah tersebut dipilih karena berdasarkan data terbaru yaitu pada tahun 2015, Badan POM melakukan pengawasan terhadap makanan jajanan anak sekolah dan menemukan puding yang mengandung zat aditif berbahaya yaitu zat metanil yellow (Metrotvnews, 2015). Berdasarkan pemaparan diatas, dilakukan penelitian dengan judul "hubungan pengetahuan tentang zat aditif dengan sikap dalam pemilihan makanan jajanan pada siswa SMPN 74 Jakarta"

\section{METODE}

Metode yang digunakan adalah metode deskriptif dengan teknik survei melalui studi korelasional. Penelitian ini dilakukan di SMPN 74 Jakarta pada bulan April-Mei 2016. Populasi target pada penelitian ini adalah seluruh siswa SMPN 74 Jakarta. Populasi terjangkau pada penelitian ini adalah seluruh siswa kelas VIII di SMPN 74 Jakarta yaitu sebanyak 285 siswa. Jumlah sampel dalam penelitian ini sebanyak 166 siswa. Pengambilan sampel dari pada penelitian ini dilakukan dengan cara random sampling.

Pada penelitian ini diperoleh data primer dan data sekunder. Data primer berupa kuesioner tes pengetahuan tentang zat aditif dan angket sikap pemilihan makanan jajanan siswa. Data sekunder berupa angket tentang sumber informasi yang didapat responden terkait pengetahuan. 


\section{PROSEDUR ANALISIS DATA}

Data instrumen tes pengetahuan tentang zat aditif dan sikap pemilihan makanan jajanan siswa diuji normalitas dengan uji Kolmogorov-Smirnov pada $\alpha=$ 0,05 dan homogenitas dengan uji Bartlett pada taraf signifikansi yang sama. Kemudian dilakukan uji signifikansi dan linieritas model regresi pada $\alpha=0,05$. Selanjutnya, dilakukan uji koefisien korelasi dengan menggunakan Pearson Product Moment pada $\alpha=0,05$ dan dilakukan perhitungan koefisien determinasi.

\section{HASIL DAN PEMBAHASAN}

\section{Hasil}

Berdasarkan hasil penelitian, nilai pengetahuan tertinggi yang diperoleh siswa adalah 100, sedangkan nilai terendah yang diperoleh siswa adalah 51. Ratarata nilai pengetahuan siswa SMPN 74 Jakarta tentang zat aditif adalah 75 . Distribusi frekuensi nilai tes pengetahuan siswa SMPN 74 Jakarta tentang zat aditif disajikan pada Gambar 1.

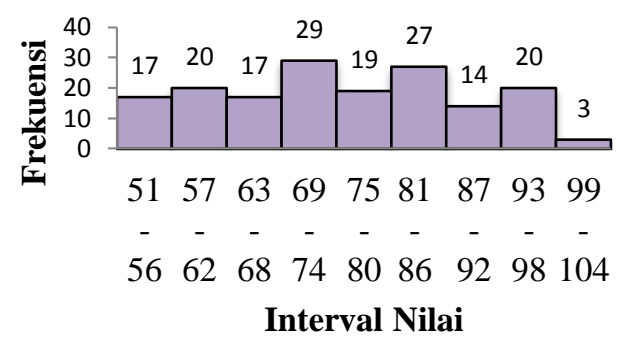

Gambar 1. Diagram batang distribusi frekuensi nilai pengetahuan siswa tentang zat aditif

Nilai pengetahuan siswa tentang zat aditif kemudian dikategorikan ke dalam 5 kategori yaitu sangat baik, baik, cukup baik, kurang baik dan sangat kurang baik. Kategori pengetahuan siswa tentang zat aditif yang terbanyak adalah kategori baik dengan jumlah siswa sebanyak 73 siswa (44\%). Perbandingan jumlah siswa berdasarkan kategori penilaian tes pengetahuan siswa tentang zat aditif dapat dilihat pada Gambar 2.

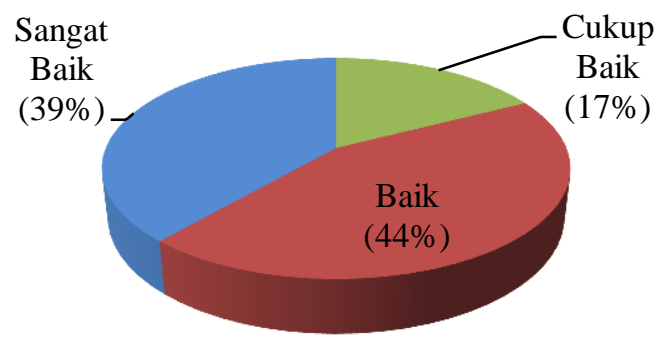

Gambar 2. Diagram lingkaran persentase jumlah siswa berdasarkan kategori penilaian tes pengetahuan siswa tentang zat aditif

Nilai pengetahuan siswa juga digambarkan berdasarkan tiga dimensi yaitu dimensi faktual, konseptual, dan prosedural. Nilai dimensi yang paling dominan adalah dimensi konseptual sebesar $77,9 \%$. Persentase nilai pengetahuan siswa tentang zat aditif berdasarkan dimensi pengetahuan disajikan pada Gambar 3. 


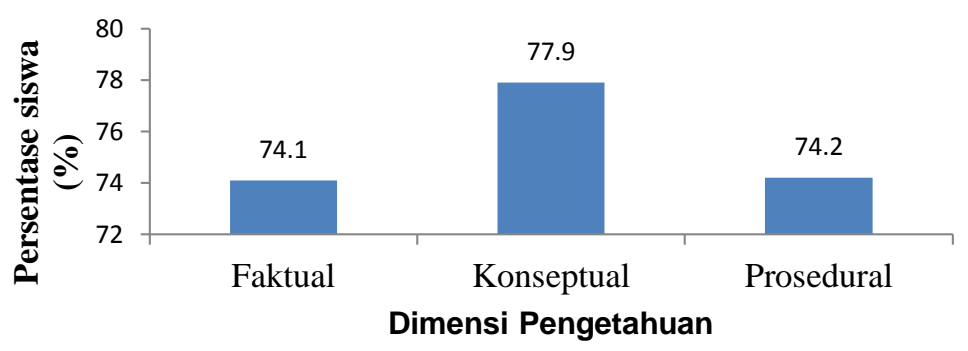

Gambar 3. Persentase nilai pengetahuan siswa tentang zat aditif berdasarkan dimensi pengetahuan

Berdasarkan hasil penelitian, nilai sikap tertinggi yang diperoleh siswa adalah 95, sedangkan nilai terendah yang diperoleh siswa adalah 60. Rata-rata nilai sikap pemilihan makanan jajanan siswa SMPN 74 Jakarta adalah 83. Distribusi frekuensi nilai sikap pemilihan makanan jajanan siswa SMPN 74 Jakarta disajikan pada Gambar 4.

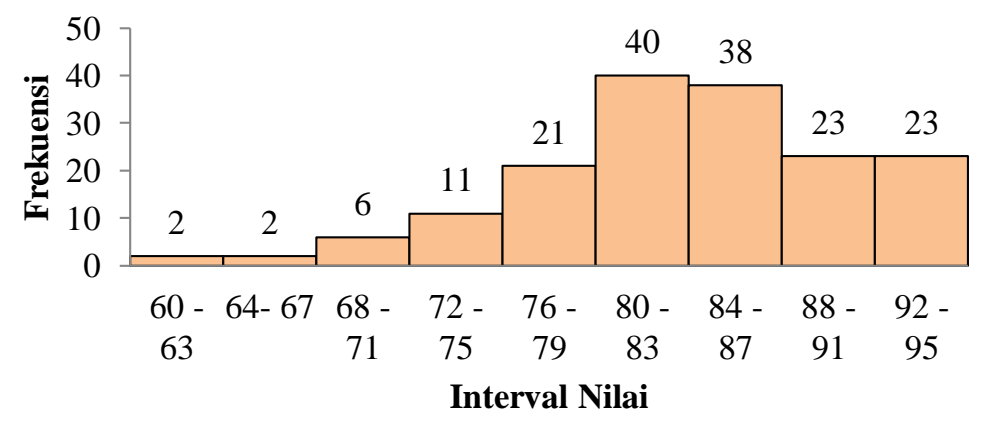

Gambar 4. Diagram batang distribusi frekuensi nilai sikap pemilihan makanan jajanan siswa

Nilai sikap pemilihan makanan jajanan siswa kemudian dikategorikan ke dalam 5 kategori yaitu sangat baik, baik, cukup baik, kurang baik dan sangat kurang baik. Kategori sikap pemilihan makanan jajanan siswa yang terbanyak adalah kategori sangat baik dengan jumlah siswa sebanyak 111 siswa (67\%). Perbandingan jumlah siswa berdasarkan kategori penilaian sikap pemilihan makanan jajanan siswa dapat dilihat pada Gambar 5.

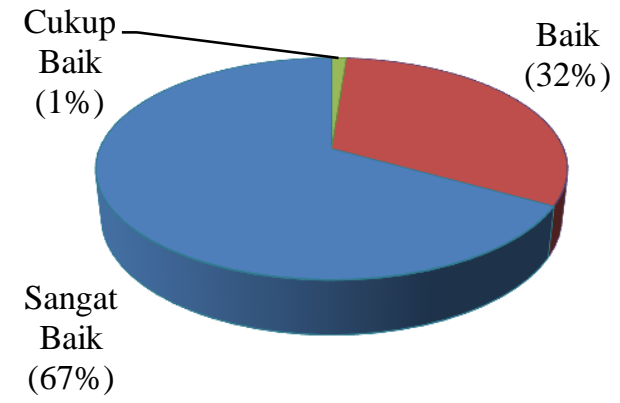

Gambar 5. Diagram lingkaran persentase jumlah siswa berdasarkan kategori penilaian sikap pemilihan makanan jajanan siswa

Nilai sikap pemilihan makanan jajanan siswa juga digambarkan berdasarkan tiga aspek sikap yaitu aspek kognitif, afektif, dan konatif. Nilai aspek sikap yang paling dominan adalah sikap kognitif sebesar $84,8 \%$. Persentase nilai 
sikap pemilihan makanan jajanan siswa berdasarkan aspek sikap disajikan pada Gambar 6.

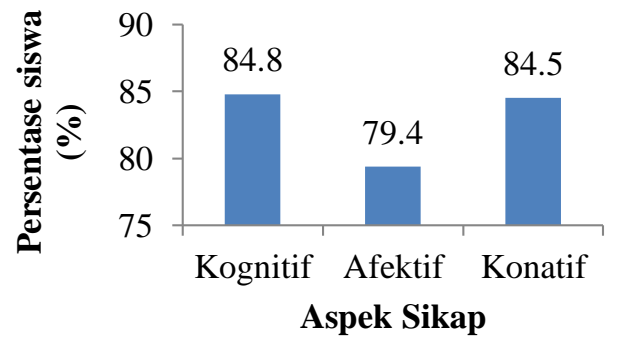

Gambar 6. Diagram batang persentase nilai sikap pemilihan makanan jajanan siswa berdasarkan aspek sikap

Berdasarkan hasil data sekunder berupa kuesioner tentang sumber informasi, diperoleh bahwa data siswa yang pernah mendengar/mendapatkan informasi tentang zat aditif sebanyak 166 (100\%) siswa. Sumber informasi tentang zat aditif yang pernah didapat siswa disajikan pada Gambar 7.

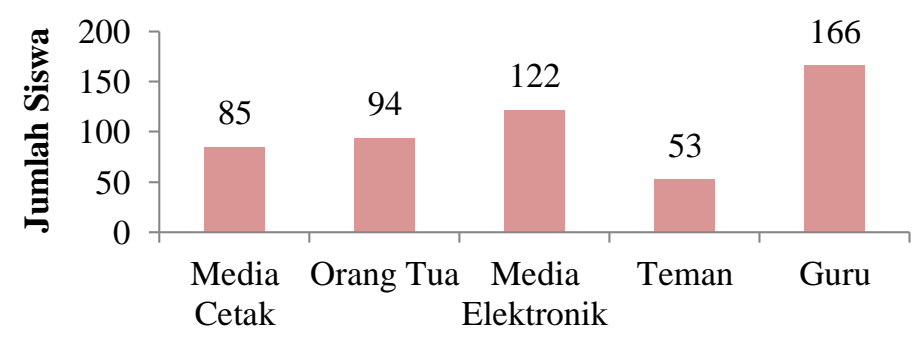

Sumber Informasi

Gambar 7. Diagram batang sumber informasi tentang zat aditif yang pernah didapat siswa

Hubungan antara tes pengetahuan siswa tentang zat aditif dengan sikap pemilihan makanan jajanan siswa dapat diketahui dengan cara membandingkan hasil kategori pengetahuan dengan hasil kategori sikap yang telah diperoleh siswa. Hubungan tes pengetahuan siswa tentang zat aditif dengan sikap pemilihan makanan jajanan siswa disajikan pada Gambar 8.

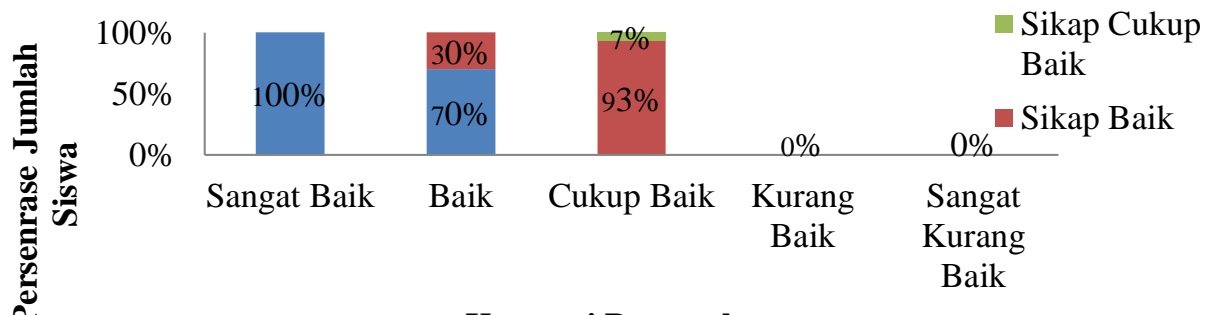

Kategori Pengetahuan

Gambar 8. Hubungan tes pengetahuan siswa tentang zat aditif dengan sikap pemilihan makanan jajanan siswa

Berdasarkan Gambar 8., diketahui terdapat 64 (100\%) siswa memperoleh nilai pengetahuan yang sangat baik dengan nilai sikap yang sangat baik; 51(70\%) siswa memperoleh nilai pengetahuan yang baik dengan nilai sikap yang sangat baik dan 22(30\%) siswa memperoleh nilai pengetahuan yang baik dengan nilai sikap yang baik; 27 (93\%) siswa memperoleh nilai pengetahuan yang cukup baik 
dengan nilai sikap yang baik dan $2(7 \%)$ siswa memperoleh nilai pengetahuan yang cukup baik dengan nilai sikap yang cukup baik juga.

Uji normalitas data dilakukan dengan menggunakan uji KolmogorovSmirnov pada taraf signifikansi $\alpha=0,05$. Berdasarkan hasil perhitungan, diketahui bahwa data populasi berdistribusi normal. Uji Homogenitas data dilakukan dengan menggunakan uji Bartlett pada taraf signifikansi $\alpha=0,05$. Berdasarkan hasil perhitungan, diketahui bahwa variansi data homogen.

Berdasarkan hasil perhitungan, diperoleh persamaan model regresi yaitu $\hat{Y}$ $=127,35+2,23 \mathrm{X}$. Berdasarkan hasil perhitungan, diketahui bahwa model regresi signifikan adalah linier. Uji koefisien korelasi dengan menggunakan rumus Pearson Product Moment. Berdasarkan perhitungan, didapat koefisien korelasi $\left(\mathrm{r}_{\mathrm{xy}}\right)$ sebesar 0,76. Nilai koefisien korelasi sebesar 0,76 menunjukkan bahwa kekuatan hubungan termasuk ke dalam kategori tinggi. Hasil koefisien korelasi menunjukkan bahwa koefisien korelasi signifikan dan terdapat hubungan positif antara pengetahuan zat aditif dengan sikap pemilihan makanan jajanan siswa. Koefisien determinasi yang diperoleh pada penelitian ini adalah 58\%.

\section{PEMBAHASAN}

Berdasarkan kategori penilaian tes pengetahuan siswa tentang zat aditif, diperoleh bahwa kategori pengetahuan siswa tentang zat aditif yang paling dominan adalah kategori baik dengan persentase jumlah siswa sebesar 44\%. Hal ini disebabkan oleh beberapa faktor seperti tingkat pendidikan, usia, dan sumber informasi.

Tingkat pendidikan siswa yang sudah mencapai jenjang SMP membuat siswa sudah mendapatkan informasi tentang zat aditif. Informasi tentang zat aditif didapatkan siswa dari mata pelajaran IPA Terpadu pada materi Bahan Kimia Dalam Bahan Makanan saat kelas VIII. Hal tersebut memungkinkan siswa untuk memiliki pengetahuan yang baik tentang zat aditif. Hal ini didukung oleh pernyataan Notoatmodjo (2007a) bahwa pendidikan dapat menambah wawasan atau pengetahuan. Seseorang yang berpendidikan lebih tinggi akan mempunyai pengetahuan yang lebih luas.

Menurut Gunarsa (2008), seseorang yang berusia 12-21 tahun termasuk ke dalam usia remaja. Pada penelitian ini, siswa berusia sekitar 13-14 tahun. Dengan demikian, dapat diketahui siswa termasuk ke dalam usia remaja. Menurut Notoatmodjo (2007), Usia mempengaruhi terhadap daya tangkap dan pola pikir seseorang. Semakin bertambahnya usia maka akan semakin berkembang pula daya tangkap dan pola pikirnya sehingga pengetahuan yang diperolehnya semakin meningkat. Oleh karena itu, usia siswa yang sudah mencapai usia remaja memungkinkan siswa lebih mudah menerima dan mengolah informasi tentang zat aditif. Informasi yang diterima dan diolah dengan baik dapat membuat siswa memiliki pengetahuan yang baik pula tentang zat aditif.

Hasil data sekunder berupa angket tentang sumber informasi menunjukkan bahwa sumber informasi tentang zat aditif yang pernah didapat siswa yaitu sebanyak $85(51 \%)$ siswa memperoleh sumber informasi dari media cetak (buku, majalah, dan koran), 94 (56\%) siswa memperoleh sumber informasi dari orang tua, $122(73 \%)$ siswa memperoleh sumber informasi dari media elektronik (radio dan tv), 53 (31\%) siswa memperoleh sumber informasi dari teman, dan 166 $(100 \%)$ siswa memperoleh sumber informasi dari guru. Berdasarkan hal tersebut 
memungkinkan siswa untuk memiliki pengetahuan yang baik tentang zat aditif. Siswa yang memiliki pengetahuan dengan nilai tertinggi memperoleh sumber informasi yang lebih banyak dari pada siswa yang memiliki pengetahuan dengan nilai yang terendah. Hal ini didukung oleh pernyataan Notoatmodjo (2007) bahwa sumber informasi seperti radio, televisi, majalah, koran, dan buku tentunya dapat memberikan wawasan yang dapat mempengaruhi pengetahuan seseorang.

Berdasarkan nilai pengetahuan siswa tentang zat aditif berdasarkan dimensi pengetahuan, nilai dimensi yang paling tinggi adalah dimensi konseptual sebesar $77,9 \%$. Hal ini menunjukkan bahwa pengetahuan konseptual adalah dimensi pengetahuan yang paling dominan mempengaruhi sikap pemilihan makanan jajanan. Pengetahuan konseptual memiliki pengaruh yang besar terhadap sikap pemilihan makanan jajanan karena menurut Anderson dan Krathwohl (2001), pengetahuan konseptual merupakan pengetahuan tentang kategori, klasifikasi, dan hubungan antar elemen dalam sebuah struktur besar yang memungkinkan elemenelemennya berfungsi secara bersama-sama, sehingga siswa dapat mengetahui kategori jenis-jenis zat aditif, fungsi zat aditif, dan dampak zat aditif terhadap kesehatan tubuh. Dengan demikian, siswa dapat lebih selektif dalam pemilihan makanan jajanan.

Berdasarkan kategori penilaian sikap pemilihan makanan jajanan siswa, diperoleh bahwa kategori sikap pemilihan makanan jajanan siswa yang paling dominan adalah kategori sangat baik dengan persentase jumlah siswa sebesar $67 \%$. Hal ini disebabkan oleh pengetahuan siswa tentang zat aditif yang sebagian besar termasuk ke dalam kategori baik. Hal ini didukung oleh pernyataan Notoatmodjo (2007) bahwa dalam menentukan sikap, pengetahuan memegang peranan penting. Selain itu, sikap pemilihan makanan jajanan siswa yang sangat baik dapat juga disebabkan oleh beberapa faktor lain. Menurut Azwar (2005), faktor yang mempengaruhi sikap seseorang yaitu pengaruh orang lain, media massa, dan lembaga pendidikan.

Pengaruh orang lain yang dianggap penting oleh siswa seperti keluarga dan guru tentu dapat membentuk sikap pemilihan makanan jajanan yang sangat baik dalam diri siswa. Pengaruh tersebut dapat berupa pemberian contoh atau pengalaman mengenai pemilihan makanan jajanan seperti menghindari makanan dengan warna yang terlalu mencolok karena kemungkinan makanan tersebut mengandung zat aditif yang berbahaya. Hal ini didukung oleh pernyataan Azwar (2005) bahwa pada umumnya, individu cenderung untuk memiliki sikap yang sama atau searah dengan sikap orang yang dianggap penting.

Media massa baik cetak maupun elektronik merupakan sumber informasi yang dapat diterima oleh masyarakat. Media massa yang memberitakan maraknya kasus penambahan zat aditif berbahaya seperti boraks dan formalin pada makanan dapat membuat siswa berhati-hati saat melakukan kegiatan jajan. Kehati-hatian siswa dapat membentuk sikap pemilihan makanan jajanan yang baik dalam diri siswa. Hal ini didukung oleh pernyataan Azwar (2005) bahwa media massa memberikan pesan-pesan yang sugestif yang mengarahkan opini seseorang. Adanya informasi baru mengenai sesuatu hal memberikan landasan kognitif baru bagi terbentuknya sikap terhadap hal tersebut.

Lembaga pendidikan dalam hal ini adalah SMPN 74 Jakarta yang merupakan tempat dimana pengetahuan diperoleh secara terstruktur. Menurut Azwar (2005), lembaga pendidikan adalah sebagai suatu sistem yang mempunyai 
pengaruh dalam pembentukan sikap dikarenakan meletakkan dasar pengertian dan konsep moral dalam diri individu sehingga memiliki pemahaman tentang baik dan buruk serta garis pemisah antar sesuatu yang boleh dan yang tidak boleh dilakukan.

Berdasarkan nilai sikap pemilihan makanan jajanan siswa berdasarkan aspek sikap, nilai aspek sikap yang paling tinggi adalah aspek kognitif sebesar 84,8\%. Hal ini menunjukkan bahwa aspek kognitif adalah aspek sikap pemilihan makanan jajanan paling dominan yang dipengaruhi oleh pengetahuan tentang zat aditif. Menurut Azwar (2005), aspek kognitif berisi pengetahuan dan kepercayaan seseorang mengenai apa yang berlaku atau apa yang benar bagi objek sikap. Hal ini menunjukkan bahwa sikap kognitif merupakan aspek sikap pemilihan makanan jajanan yang paling dominan karena banyak siswa yang memiliki pengetahuan yang baik tentang zat aditif.

Berdasarkan hasil penelitian, nilai koefisien korelasi sebesar 0,76. Hal ini menunjukkan bahwa kekuatan hubungan antara pengetahuan tentang zat aditif dengan sikap pemilihan makanan jajanan siswa termasuk ke dalam kategori tinggi. Hasil penelitian ini juga menunjukkan adanya hubungan yang positif antara pengetahuan tentang zat aditif dengan sikap pemilihan makanan jajanan siswa. Hubungan yang positif dan kekuatan hubungan yang tinggi dalam hal ini menunjukkan bahwa semakin baik pengetahuan tentang zat aditif maka sikap pemilihan makanan jajanan juga akan semakin baik. Hasil penelitian ini juga didukung oleh hasil penelitian Sudarmawan dan Nurhayati (2013) yang mengatakan bahwa terdapat hubungan yang positif antara pengetahuan tentang makanan jajanan dengan sikap anak memilih jajanan.

Berdasarkan hasil penelitian, diketahui terdapat siswa yang memperoleh nilai pengetahuan yang sangat baik dengan nilai sikap yang sangat baik, siswa memperoleh nilai pengetahuan yang baik dengan nilai sikap yang baik, dan siswa memperoleh nilai pengetahuan yang cukup baik dengan nilai sikap yang cukup baik juga. Hal ini menunjukkan bahwa semakin baik pengetahuan tentang zat aditif maka sikap pemilihan makanan jajanan juga akan semakin baik. Hal ini didukung oleh pernyataan Notoatmodjo (2007) bahwa pengetahuan memegang peranan penting dalam pembentukan suatu sikap. Pengetahuan yang dimiliki seseorang akan diproses dalam dirinya dan menjadi suatu kepercayaan sehingga membentuk sikap seseorang terhadap suatu objek, dalam hal ini pengetahuan tentang zat aditif yang dimiliki siswa akan diproses dalam dirinya dan menjadi suatu kepercayaan sehingga membentuk sikap pemilihan makanan jajanan. Namun, ditemukan pula hasil yang berbeda yaitu terdapat siswa yang memperoleh nilai pengetahuan yang baik dengan nilai sikap yang sangat baik dan siswa yang memperoleh nilai pengetahuan yang cukup baik dengan nilai sikap yang baik. Hal ini menunjukkan terdapat faktor-faktor lain yang mempengaruhi sikap pemilihan makanan jajanan selain pengetahuan misalnya pengaruh orang lain dan media massa. Untuk mengetahui seberapa besar kontribusi pengetahuan tentang zat aditif dalam pembentukan sikap pemilihan makanan jajanan, maka dilakukan perhitungan koefisien determinasi.

Berdasarkan hasil perhitungan, diketahui bahwa nilai koefisien determinasi sebesar 58\%. Hal tersebut menunjukkan pengetahuan tentang zat aditif memberikan sumbangan/kontribusi sebesar $58 \%$ terhadap sikap pemilihan makanan jajanan siswa, sedangkan $42 \%$ disebabkan oleh faktor-faktor lain. 
Menurut Azwar (2005), faktor lain yang mempengaruhi sikap seseorang yaitu pengaruh orang lain, media massa, dan lembaga pendidikan. Menurut hasil penelitian Kristianto, Riyadi, dan Mustafa (2013), faktor lain yang mempengaruhi sikap pemilihan makanan jajanan yaitu hadiah pada makanan.

\section{KESIMPULAN}

Kesimpulan dari hasil penelitian ini adalah terdapat hubungan positif antara pengetahuan tentang zat aditif dengan sikap pemilihan makanan jajanan siswa SMPN 74 Jakarta. Terdapatnya hubungan yang positif menunjukkan bahwa semakin baik pengetahuan tentang zat aditif maka sikap pemilihan makanan jajanan siswa SMPN 74 Jakarta juga akan semakin baik

\section{DAFTAR PUSTAKA}

Almatsier, S. (2013). Prinsip Dasar Ilmu Gizi. Jakarta: PT Gramedia Pustaka Utama.

BPOM RI. (2014). Laporan Kinerja Badan Pengawas Obat Dan Makanan RI Tahun 2014. Diakses dari http://www.pom.go.id pada 15 Februari 2016

Cahyadi, W. (2006). Analisis \& Aspek Kesehatan Bahan Tambahan Pangan. Jakarta: PT. Bumi Aksara.

Menteri Kesehatan Republik Indonesia. (2003). Keputusan Menteri Kesehatan Republik Indonesia Nomor 942 tentang Pedoman Persyaratan Hygiene Sanitasi Makanan Jajanan. Jakarta: Kementrian Kesehatan Republik Indonesia.

Metrotvnews. (2015). Ditemukan Puding Mengandung Zat Berbahaya, SMPN 74 Mengaku Kecolongan. Diakses dari www.news.metrotvnews.com pada 20 Januari 2016.

Notoatmodjo, S. (2007). Kesehatan Masyarakat Ilmu dan Seni. Jakarta: PT. Rineka Cipta.

Notoatmodjo, S. (2007a). Promosi Kesehatan dan Ilmu Perilaku. Jakarta: PT. Rineka Cipta.

Nuraini, H. (2007). Memilih \& Membuat Jajanan Anak yang Sehat \& Halal. Jakarta: QultumMedia.

Purnomowati, I., Hidayati, D., dan Saparinto, C. (2008). Aneka Kudapan Berbahan Ikan. Yogyakarta: Kanisius.

Sudarmawan dan Nurhayati, F. (2013). The Relationship Between Knowledge About The Various Snack Choice and The Food Selecting Of Children's Attitudes In SDN Sambikerep II/480 Surabaya. Jurnal Pendidikan Olahraga dan Kesehatan. 1(1), 113-117.

Sunaryo. (2004). Psikologi Untuk Keperawatan. Jakarta: Penerbit Buku Kedokteran EGC. 